\title{
ARHGAP45 Gene
}

National Cancer Institute

\section{Source}

National Cancer Institute. ARHGAP45 Gene. NCI Thesaurus. Code C157544.

This gene is involved in the activation of Rho-type GT Pases. 